Рефлексивний компонент педагогічного такту вчителя початкових класів передбачає наявність здатності до самоспостереження, самопізнання, самоаналізу, самоконтролю та узагальнення отриманих знань, умінь, навичок, співвіднесення себе, своїх можливостей 3 тим, чого вимагає обрана професія.

Отже, зазначене вище дає підстави стверджувати, що педагогічний такт учителів початкових класів - це складне особистісне утворення, що характеризується почуттям міри в застосуванні педагогічного впливу на молодших школярів, у взаємодії і спілкуванні з учнями та їх батьками, урахованні особливостей віку дітей і специфіки професійних функцій. Структура цього феномену містить особистісно-вольовий, інтелектуальний, рефлексивний і комунікативний компоненти. На формування цих компонентів слід звернути увагу під час професійної підготовки майбутнього вчителя початкових класів у вищому педагогічному навчальному закладі.

\title{
Література
}

1. Васильсва М. П. Сучасний стан дослідження питань професійної деонтології / М. П. Васильєва, М. К. Подберезський // Засоби навчальної та науково-дослідної роботи: [зб. наук. праць] / за заг. ред. В. І. Свдокимова і проф. О. М. Микитюка. - Харків, 2010. Вип. 33. - С. 177. 2. Гончаренко С. У. Український педагогічний словник / Семен Устинович Гончаренко. - Київ : Либідь, 1997. - 376 с. З. Кутняк І. Особливості підготовки майбутніх учителів початкових класів у світлі завдань сучасної вищої школи / І. Кутняк // Початкова школа. - 2014. - № 10. - С. 28-30. 4. Мірошник 3. М. Структура особистості вчителя початкових класів: рольовий підхід : [монографія] / Зоя Михайлівна Мірошник. Харків : ФЛП Шейнина Е. В.; ХНПУ, 2011. - 306 с. 5. Словник іншомовних слів / авт. колектив: Л. І. Шевченко, О. І. Ніка, О. І. Хом'як, А. А. Дем'янюк; за ред. Л. І. Шевченко. Київ : АРІЙ, 2008. - 672 с. б. Страхов И. В. Психологические основы педагогического такта: [пособ. для ин-тов] / Иван Владимирович Страхов. - Саратов, 1972.- 180 с. 7. Сухомлинський В. О. Методика виховання колективу / В. О. Сухомлинський // Вибрані твори: в 5 т. - Київ, 1976. - Т. 1. - С. 613-637. 8. Сухомлинський В. О. Не бійтеся бути ласкавим / В. О. Сухомлинський // Вибрані твори: в 5 т. - Київ, 1977. - Т. 5. - С. 317-359. 9. Сухомлинский В. А. Сто советов учителю / В. А. Сухомлинский. - Київ : Рад. школа, 1984.- 254 с. 10. Федорова Л. Г. Формування педагогічного такту - основа професійної підготовки майбутнього фахівця / Л. Г. Федорова // Актуальные вопросы в современной науке: [сб. научных докладов]. - Варшава, 2013. - Часть 3/2. - С. 42-50.

УДК 37.013 .42

Юлія Чернецька

\section{ПОНЯТІЙНА ТРІАДА «СОЦІАЛІЗАЦІЯ - ДЕСОЦІАЛІЗАЦІЯ - РЕСОЦІАЛІЗАЦІЯ» В КОНТЕКСТІ ВИВЧЕННЯ СОЦІАЛЬНО-ПЕДАГОГІЧНИХ ПРОБЛЕМ НАРКОЗАЛЕЖНИХ ОСІБ}

Чернецька Ю. І.Понятійна тріада «соціалізація - десоціалізація - ресоціалізація» в контексті вивчення соціально-педагогічних проблем наркозалежних осіб.

У статті розкрито зв'язок дефініцій «соціалізація», «десоціалізація» і «ресоціалізація», який представлено як понятійну тріаду. Розроблено наукові основи і подано сутнісні характеристики процесу ресоціалізації наркозалежних осіб з позицій соціальної педагогіки. Розкрито сутність провідних понять «ресоціалізація», «ресоціалізація наркозалежних».

Ключові слова: понятійна тріада, соціалізація, десоціалізація, ресоціалізація, 
наркозалежні особи.

Чернецкая Ю. И. Понятийная триада «социализация - десоциализация ресоциализация» в контексте изучения социально-педагогических проблем наркозависимых лиц.

В статье раскрыта связь дефиниций «социализация», «десоциализация» и «ресоциализация», которая представлена в виде понятийной триады. Разработаны научные основы и поданы сущностные характеристики процесса ресоциализации наркозависимых лиц с позиций социальной педагогики. Раскрыта сущность ключевых понятий «ресоциализация», «десоциализация наркозависимых».

Ключевые слова: понятийная триада, социализация, десоциализация, ресоциализация, наркозависимые лица.

Chernetskaya Yu. I. Conceptual triad of «socialization - desocialization - resocialization» in the context of the study of social and educational problems of drug-addicted people.

The article reveals the connection between definitions «socialization», «desocialization» and «resocialization», which presented as a conceptual triad. The scientific basis has been developed and the essential characteristics of the resocialization process of drug-addicted people in terms of social pedagogy have been given. The essence of the key concepts «resocialization», «resocialization of drug-addicted people» has been shown.

Key words: conceptual triad, socialization, desocialization, resocialization, drug-addicted people.

Актуальність проблеми повернення наркозалежних осіб до соціального середовища зумовлена багатоаспектністю наявних наукових підходів до розуміння соціалізаційної проблематики, вироблених у різних галузях знання, та різноманітністю поглядів на природу соціалізації, десоціалізації та ресоціалізації осіб 3 адиктивною поведінкою, а також недостатньою розробленістю теоретико-методологічних основ процесу ресоціалізації наркозалежних із соціально-педагогічних позицій.

Метою статті є визначення ролі та місця категорії «ресоціалізація наркозалежних» у понятійній тріаді «соціалізація - десоціалізація - ресоціалізація», визначення сутності поняття «ресоціалізація наркозалежних осіб», теоретичне розробка основних концептуальних поглядів на сутність процесу ресоціалізації наркозалежних.

Аналіз останніх публікацій соціалізаційної проблематики свідчить, що окремим аспектам зазначеної проблеми присвячено роботи дослідників різних галузей гуманітарних наук, зокрема, методологічним основам процесу соціалізації з позицій соціальної філософії приділяли увагу І. Кон, М. Лукашевич, I. Милославова, В. Москаленко, різні аспекти соціалізації особистості у групі, колективі досліджували А. Ковальова, В. Паригін, А. Петровський, 3 позицій соціальної психології теорію соціалізації збагатили роботи Г. Андреєвої, Є. Кузьміна, пенітенціарні основи соціалізації правопорушників вивчено І. Богатирьовим, В. Горенком, Л. Жук, Л. Караман, О. Неживець, В. Синьовим, В. Радовим, соціально-педагогічну проблематику, зокрема стосовно соціалізації різних категорій осіб розкрили у своїх роботах розкрили сучасні вітчизняні та зарубіжні науковці А. Капська, Л. Мардахаєв, А. Мудрик, С. Харченко та інші. Ірунтовних теоретичних розвідок, які б стосувалися саме ресоціалізації наркозалежних осіб, ми не виявили, що викликає необхідність теоретичного дослідження соціально-педагогічного аспекту проблеми 
ресоціалізації такої категорії осіб.

Уважаємо за необхідне розпочати розгляд заявленої проблеми з аналізу провідних понять, які, на думку науковців - А. Капської, Л. Мардахаєва, С. Харченка, складають понятійну тріаду «соціалізація - десоціалізація - ресоціалізація».

Розкриваючи сутність зазначеної тріади, зосередимо увагу на існуючій у науці ідеї про те, що діалектична взаємозумовленість деяких з категорій дозволяє складати 3 них як понятійні пари (зокрема, загальновідомі: можливість і дійсність, причина i наслідок, необхідність і випадковість), так і так звані понятійні тріади: «матерія - простір - час», «форма - зміст - суть» тощо [11].

Процес виникнення понятійних діад та тріад, що характерний для категоріальної бази гуманітарних наук, зокрема філософії, психології, педагогіки тощо, спостерігається й у термінологічному полі соціальної педагогіки. Інтерес для нас становить філософський погляд на поняття «тріада» (з грец. trias, triados - троїчність, єдність трьох осіб, предметів, понять), що означає вищий ступінь єдності категорій, які саме у своїй троїчності найбільш повно відображають сутність предметів і явищ. Під понятійною тріадою в психології індивідуальності розуміють диференціальний трикомпонентний опис різних проявів індивідуальності, у якому розділяються поняття, що належать до різних аспектів однієї онтологічної реальності (наприклад, розум - воля - почуття, здібності - талант обдарованість).

У понятійній тріаді «соціалізація - десоціалізація - ресоціалізація» кожна категорія, як правило, зумовлена двома іншими, визначається ними й залежить від їх наявності. Йдеться скоріше про атрибутивність досліджуваних категорій, тобто про необхідні умови їх існування. Дійсно, якщо не відбувається соціалізація, особистість, відповідно, не може буде десоціалізованою, оскільки на неї не впливають компоненти соціалізації (агенти, механізми, засоби), тим більше немає потреби в ресоціалізації, оскільки не маємо десоціалізованої особистості. Саме так проявляється їх взаємообумовленість та єдність. Таке бачення підтверджується важливою для нас думкою С. Харченка про те, що всі дефініції зазначеної тріади не тільки є близькими семантично, а й відбивають триєдиний процес: знаходження людиною соціальних зв'язків (соціалізація), їхня руйнація (десоціалізація), відновлення втраченої соціальності (ресоціалізація). У досліджуваній нами тріаді поняття «ресоціалізація» не є самодостатнім. Воно, на думку згаданого науковця, є «не тільки семантичною, але й сутнісною похідною базової категорії «соціалізація» й відбиває певний етап в особистісному розвитку, зберігаючи при цьому єдину логіку загальноресоціалізаційного процесу» [13, с. 53]. До того ж, такий підхід базується на принципі системності, що передбачає розгляд усіх елементів цілісної множини як системного цілого, тому визначити сутнісні характеристики ресоціалізації, не аналізуючи категорію «соціалізація» неможливо. Зазначимо, що означений семантичний конструкт має не тільки внутрішньосмислові родові зв'язки, які потребують уточнення в межах нашого дослідження, a ще кожна 3 його дефініцій («соціалізація», «десоціалізація» $\mathrm{i}$ «ресоціалізація») визначається науковцями в різних контекстах, і потребує виявлення зовнішньо категоріальних зв'язків у широкому науковому полі. Визначившись із суттю похідної в межах логічного підходу дефініції «соціалізація» можна аналізувати інші структурні складники досліджуваної понятійної тріади, які складають концептуальну основу нашого дослідження i наближають нас до розуміння суті понять «ресоціалізація» $\mathrm{i}$ «ресоціалізація наркозалежних осіб».

Спираючись на роботи провідних науковців щодо соціалізаційного процесу 
А. Капської, М. Лукашевича, А. Мудрика, С. Харченка, зазначимо, що розгляд понятійної тріади «соціалізація - десоціалізація - ресоціалізація» можна проводити за допомогою двох підходів: логіко-понятійного (рід - вид) і системно-структурного (частина - ціле). Задля виявлення родо-видового співвідношення дефініцій у зазначеній тріаді та можливості подальшого з'ясування суті «ресоціалізація наркозалежних», виокремлення іiї відмінностей від інших споріднених понять, доведення ії права на окреме існування в системі наукових дефініцій як важливої категоріальної одиниці, звернемося до аналізу родового поняття «соціалізація», яке є одним із центральних у соціально-педагогічній науці.

Звертаючись до генезису поняття «соціалізація», відзначимо, що спочатку в широкому науковому i практичному обігу воно використовувалося у контексті, дещо відмінному від сучасного розуміння, й з часом почало позначати «розвиток соціальної природи людини або характеру індивіда, підготовку людського матеріалу до соціального життя» [9, с. 8].

Найбільш усталені сучасні наукові погляди на сутність досліджуваного поняття знаходимо в довідкових та енциклопедичних джерелах, яких «соціалізація» розуміється як: «двобічний процес засвоєння індивідом соціального досвіду (цінностей, норм, поведінки) того суспільства, до якого він належить, i активне відтворення і збагачення системи соціальних зв'язків і відносин, у яких він розвивається; складний i тривалий процес включення індивіда до системи соціальних зв'язків та відносин, його активної взаємодії 3 соціальним середовищем, у результаті якої він засвоює зразки поведінки, соціальні норми і цінності, необхідні для його успішної життєдіяльності в суспільстві [3, с. 421].

До визначень, які найчастіше використовуються у вітчизняній науковій літературі, належать тлумачення науковців соціально-філософського (С. Батенін, М. Лукашевич, В. Москаленко, В. Паригін) й соціально-психологічного напряму (Г. Андреєва, I. Кон, О. Леонтьєв), роботи яких суттєво вплинули на розвиток категоріального апарату соціальнопедагогічної науки. До них, на наш погляд, належать тлумачення дефініції «соиіалізація», які відображають і діяльність особистості, і вплив соціального середовища, I. Кона: «засвоєння індивідом соціального досвіду, в ході якого створюється конкретна особистість» [7]; Г. Андреєвої: «двобічний процес, який містить, 3 одного боку, засвоєння індивідом соціального досвіду шляхом входження в соціальне середовище, систему соціальних зв'язків, з іншого, - процес активного відтворення системи соціальних зв'язків за рахунок його активної діяльності, активного включення в соціальне середовище» [1]; Є. Кузьміна: «входження особистості в групу на основі таких механізмів соціалізації, як наслідування, навіювання, конформізм, свідоме дотримання зразків, вплив засобів масової комунікації й культури» [6]. Отже, «термінологічний рух», який виник у межах соціальної філософії та соціальної психології, зумовив специфічне тлумачення соціалізації, притаманне категоріальному апарату, власне, соціальної педагогіки як науки, відображаючи в широкому контексті певну усталену модель людських взаємодій у соціальному середовищі, результатом яких $\epsilon$ «усуспільнення» індивідів у соціумі, їх соціокультурний розвиток, надбання соціального досвіду, соціальності. Так, із позицій соціальної педагогіки А. Капська, С. Харченко визначають соціалізацію як двобічний процес, який містить і засвоєння індивідом соціального досвіду шляхом входження в соціальне середовище, й активне відтворення ним системи соціальних зв'язків за рахунок своєї активної діяльності [12; 13]; А. Мудрик розглядає соціалізацію як «розвиток і саморозвиток людини у процесі освоєння і відтворення культури, що відбувається в результаті взаємодії людини зі стихійними, відносно спрямованими і цілеспрямовано створеними умовами життя на всіх вікових 
етапах» [9, с.9]; Л. Мардахаєв вбачає соціалізацію у процесі становлення особистості, засвоєння індивідом мови, соціальних цінностей і досвіду (норм, установок, зразків поведінки), культури, відтворення і збагачення ним соціальних зв'язків і соціального досвіду [8, с. 43].

Визначені термінологічні акценти дозволяють зрозуміти суть соціалізації як основної системоутворювальної категорії тріади. Водночас десоціалізацію можемо визначити як процес руйнування засвоєних особистістю соціальних норм, цінностей і зразків поведінки, що відбувається під впливом негативної соціальної взаємодії, асоціальних умов середовища. Проте, термінологічний аналіз буде не повним, якщо ми не зазначимо, що для уточнення перебігу процесу десоціалізації в науковому обігу наявний термін «асоціалізація», зміст якого полягає в засвоєнні під час десоціалізації особистістю антисуспільних, антисоціальних норм, цінностей, негативних ролей, установок, стереотипів поведінки, які об'єктивно призводять до деформації соціальних зв'язків та дестабілізації людини в суспільстві. Розширюючи уявлення щодо суті поняття «десоціалізація», зауважимо, що між соціалізацією і десоціалізацією особистості в певний проміжок часу відбуваються якісні видозміни: особистість втрачає набуті раніше соціально схвалені моделі поведінки, втрачає або переорієнтовує на інші (наприклад, антисуспільні) цінності, ігнорує або порушує соціальні норми. Ця думка підтверджується дослідженнями науковців. Так, спираючись на думку А. Ковальової, можна стверджувати: процес десоціалізації сигналізує, що на певній стадії відбувається деформація особистості (здебільшого під впливом негативного мікросередовища), що виникає внаслідок відчуження індивіда від інститутів соціалізації, які $\epsilon$ носіями моральних, правових та інших норм. Результатом є руйнація попередніх позитивних норм та цінностей і засвоєння антигромадських взірців поведінки [5, с. 184-185]. У зв'язку з цим, на наш погляд, важливо висловити думку про ступінь десоціалізації наркозалежних осіб, який визначається розривом між засвоєним і відтвореним соціально позитивним досвідом, що й зумовлює процес ресоціалізації [14].

Дотримуючись логіки нашого дослідження, розглянемо «ресоціалізацію» як ключовий складник понятійної тріади «соціалізація - десоціалізація - ресоціалізація», і зазначимо, що вона походить від поєднання латинського префікса «re»- повторний, зворотний, та пізньолатинського морфа «socialis», що означає суспільний. В означеному понятті префікс «ре» означає повторну дію або дію, що позначає поновлення; протидію асоціалізації чи десоціалізації, прищеплення тих цінностей i взірців поведінки, які схвалюються суспільством [8, с. 47].

У сучасних джерелах наявня низка тлумачень досліджуваної дефініції достатньо близьких за значенням, які, проте, мають і деякі відмінності, тому традиційно розпочнемо аналіз поняття «ресоціалізація» із вивчення довідкових джерел. В енциклопедичних джерелах і спеціальній довідковій літературі термін «ресоціалізація» розуміється як, процес засвоєння нових знань, цінностей, ролей, навичок замість колишніх [3, с. 373]; повторна соціалізація, підготовка до повернення індивіда до звичної культури, середовища, відновлення соціальних зв'язків через зміну установок, цілей, норм і цінностей його життя [4, с. 72].

Як бачимо, змістовим стрижнем усіх наведених визначень є оновлення норм, цінностей, соціального досвіду особистості; це дозволяє зрозуміти, що саме необхідно запропонувати наркозалежній особі задля створення можливості іiі повернення в соціум.

Ураховуючи специфіку нашого дослідження, звернемося до довідкової літератури соціально-педагогічного спрямування й зауважимо, що серед проаналізованих джерел лише 
в одному дефініція «ресоціалізація» опосередковано стосується категорії наркозалежних (алкозалежних) осіб як напряму державної політики стосовно роботи 3 молоддю, решта джерел зосереджуються на детальних характеристиках ресоціалізації засуджених. Отже, у словнику-довіднику для соціальних педагогів і соціальних працівників «ресоціалізація» тлумачиться, як: відновлення особистістю якостей, необхідних для нормальної життєдіяльності в суспільстві; засвоєння нових цінностей, ролей, навичок замість попередніх; комплекс заходів, спрямований на відновлення соціального статусу особистості, втрачених або несформованих соціальних навичок, переорієнтація соціальних і референтних орієнтацій девіантів за рахунок залучення їх до нових стосунків і видів діяльності». Проте для нас найбільш важливим є визначення ресоціалізації наркозалежних, водночас не менший науковий інтерес викликає також i змістове наповнення категорії «ресоціалізація засуджених», тому що майже 60 \% 3 наркозалежних мали проблеми 3 правоохоронними органами, а деякі з них відбували термін покарання в пенітенціарних закладах. У соціальній педагогіці дефініція «ресоціалізація» стосовно делінквентних осіб є достатньо розробленим терміном, на відміну від «ресоціалізації наркозалежних осіб», але для змістового розведення цих двох понять і конкретизації досліджуваного поняття, наведемо деякі визначення ресоціалізації з позицій пенітенціарної педагогіки: підтримка соціально корисних зв'язків, відновлення їх через систему заходів, передбачених державою і застосованих до осіб, які вчинили злочини, задля їх корекції, а також підтримки, зміцнення та становлення соціально корисних зв'язків, порушених унаслідок антисоціальної протиправної поведінки суб'єкта» (I. Богатирьов) [2, с. 23-24]; процес соціального відновлення особи, яка скоїла злочин і засуджена до покарання, як соціалізованого члена суспільства, що здійснюється на основі застосування до неї комплексу правових, організаційних, психолого-педагогічних, виховних та інших заходів впливу на різних етапах кримінальної відповідальності задля недопущення здійснення протиправних дій та повернення iї до самостійного загальноприйнятого соціального життя в суспільстві [10, с. 15-16].

Зіставлення наведених у науково-довідковій літературі визначень провідної дефініції «ресоціалізації» в пенітенціарному контексті переконує, що зазначені вище терміни не повною мірою відображають сутність ресоціалізації наркозалежних осіб, оскільки всі вони обмежуються корекційно-виправними діями примусового порядку, не враховуючи того, що наркозалежні по суті є хворими людьми (тобто, спочатку потребують медичної, зокрема фізіологічної реабілітації, а потім психологічної і соціальної), однак, спільним є те, що, як і засуджені, наркозалежні перебувають в ізольованому від загального соціуму середовищі середовищі реабілітаційного центру. Тому, спираючись на попередні визначення сутності процесу ресоціалізації (В. Синьов, С. Харченко та ін.), представимо власне розумінням поняття «ресоціалізащії наркозалежних осіб» як «відновлення, збереження й розвиток соціально корисних зв'язків і відносин наркозалежної особи із сочіальним середовищем, формування нових соціально схвалених моделей поведінки, норм і иінностей, позитивного соиіального досвіду задля повноцінного функиіонування в суспільстві як у період проходження реабілітащії, так і на подальших етапах життєдіяльності».

Намагаючись узагальнити одержане нами у процесі термінологічного аналізу поняття про можливе визначення дефініції «ресоціалізація наркозалежних осіб», зазначимо, що воно детермунється так:

- як процес відновлення якостей особистості, які дозволяють їй функціонувати в суспільстві як повноцінним членом;

- як діяльність, спрямована на відновлення взаємодії особистості в рамках соціально 
схваленої поведінки, яка виявляється через соціально позитивні зв'язки;

- як результат, що характеризується певною спільністю людини і середовища через відтворення соціального досвіду і соціокультурного розвитку.

Отже, у представленій понятійній тріаді «соціалізація - десоціалізація ресоціалізація» кожна категорія обумовлена двома іншими, визначається ними й залежить від них, відбиваючи сутність триєдиного процесу знаходження людиною соціальних зв 'язків. Досліджувана тріада покладена в основу вироблення концептуального підходу щодо визначення сутності та складників ресоціалізаційного процесу. Процес ресоціалізації характеризується, по-перше, не лінійністю реалізації, а характером циклічності (кожен повторний цикл ресоціалізації можливий якщо рівень, десоціалізації наркозалежної особистості перевищує рівень іiі ресоціалізованості, а за умови успішної ресоціалізації цей процес 3 часом перетворюється на соціалізацію); по-друге, високий рівень ресоціалізованості, що за якістю наближається до соціалізованості та соціальності, забезпечує профілактику повторної ресоціалізації, що може виникнути у разі рецидиву вживання психоактивних речовин наркозалежною особою.

Перспективними напрямами подальшого дослідження ресоціалізаційної проблематики стануть питання організаційного i методичного забезпечення процесу ресоціалізації наркозалежних осіб, створення сприятливого середовища ресоціалізації та підготовки суб'єктів до здійснення соціально-педагогічної роботи 3 ресоціалізації наркозалежних у такому середовищі.

\section{Література}

1. Андреева Г. М. Социальная психология / Г. М. Андреева. - Москва : Аспект-пресс, 1996. - 376 с. 2. Богатирьов I. Г. Створення системи ресоціалізації засуджених / І. Г. Богатирьов // Проблеми пенітенціарної теорії і практики. - Київ : 1998. - № 3. - С. 2324. 3. Все про соціальну роботу: [навч. енциклопедичний словник-довідник] / за наук. ред. д. с. н., проф. В. М. Пічі.- [3-тє вид., випр., перероб. та доп.]. - Львів : Новий світ - 2000, 2014. - 618 с. 4. Енциклопедія для фахівців соціальної сфери / за заг. ред. І. Д. Звєрєвої. Київ, Сімферополь : Універсум, 2013. - 536 с. 5. Ковалева А. И. Десоциализация / А. И. Ковалева // Знание. Понимание. Умение. - 2006. - № 1. - С. 184-185. б. Кузьмин Е. С. Основы социальной психологии / Е. С. Кузьмин. - Ленинград : Изд-во ЛГУ, 1967. - 173 с. 7. Кон И. С. Социология личности / И. С. Кон. - Москва : Политиздат, 1967. - 383 с. 8. Мардахаев Л. В. Социальная педагогика : [учебник] / Лев Владимирович Мардахаев. Москва : Гардарики, 2005. - 269 с. 9. Мудрик А. В. Социальная педагогика : [учеб. для студ. пед. вузов] / А. В. Мудрик; под ред. В. А. Сластенина. - [3-е изд., испр. и доп.]. - Москва : Издательский центр «Академия», 2000. - 200 с. 10. Неживець О. Ресоціалізація засуджених та осіб, звільнених з місць позбавлення волі: [монографія] / О. М. Неживець, Л. А. Жук, І. Л. Жук. - Київ : Кондор, 2009. - 222 с. 11. Поляков А. Ф. Проблема понятийной триады «форма-содержание-смысл»/ А.Ф. Поляков [Электронный ресрус]. - Режим доступу : http://cyberleninka.ru/article/n/problema-ponyatiynoy-triady-forma-soderzhanie-smysl

12. Соціальна педагогіка: [підручник] / за редакцією А. Й. Капської. - К. : Центр навчальної літератури, 2006. - 468 с. 13. Харченко С. Я. Соціалізація дітей та молоді в процесі соціально-педагогічної діяльності : теорія та практика : [монографія] / С. Я. Харченко.Луганськ : Альма-матер, 2006. - 320 с. 14. Чернецька Ю. I. Соціально-педагогічні умови ресоціалізації наркозалежної молоді в реабілітаційному центрі / Ю. І. Чернецька // Культурологія та соціальні комунікації: інноваційні стратегії розвитку : матеріали між нар. наук. конф. (Харків, 18-19 листоп. 2010 р.). - Харків : ХДАК, 2010. - 296 с. 